\title{
Whole-exome sequencing to identify somatic mutations in peritoneal metastatic gastric adenocarcinoma: A preliminary study
}

\author{
Hao Liu ${ }^{1, *}$, Fengping $\mathrm{Li}^{1, *}{ }^{*}$, Yu Zhu ${ }^{1}$, Tingting $\mathrm{Li}^{1}$, Haipeng Huang ${ }^{1}$, Tian Lin ${ }^{1}$, Yanfeng \\ $\mathbf{H u}^{1}$, Xiaolong $\mathbf{Q}^{1}{ }^{1}$, Jiang $\mathbf{Y u}^{1}$, Guoxin $\mathbf{L i}^{1}$ \\ ${ }^{1}$ Department of General Surgery, Nanfang Hospital, Southern Medical University, Guangzhou, Guangdong, China \\ *These authors contributed equally to this work and should be considered co-first authors \\ Correspondence to: Guoxin Li, email: gzliguoxin@163.com \\ Jiang Yu, email: balbc@163.com \\ Keywords: gastric cancer, peritoneal metastasis, whole-exome sequencing (WES), Sanger sequencing, somatic mutation \\ Received: February 21, $2016 \quad$ Accepted: May 16, $2016 \quad$ Published: May 30, 2016
}

\section{ABSTRACT}

Peritoneal metastasis occurs in more than half of patients with unresectable or recurrent gastric cancer and is associated with the worst prognosis. The associated genomic events and pathogenesis remain ambiguous. The aim of the present study was to characterize the mutation spectrum of gastric cancer with peritoneal metastasis and provide a basis for the identification of new biomarkers and treatment targets. Matched pairs of normal gastric mucosa and peritoneal tissue and matched pairs of primary tumor and peritoneal metastasis were collected from one patient for whole-exome sequencing (WES); Sanger sequencing was employed to confirm the somatic mutations. G $>A$ and $C>T$ mutations were the two most frequent transversions among the somatic mutations. We confirmed 48 somatic mutations in the primary site and 49 in the peritoneal site. Additionally, 25 non-synonymous somatic variations (single-nucleotide variants, SNVs) and 2 somatic insertions/deletions (INDELs) were confirmed in the primary tumor, and 30 SNVs and 5 INDELs were verified in the peritoneal metastasis. Approximately $59 \%$ of the somatic mutations were shared between the primary and metastatic site. Five genes (TP53, BAI1, THSD1, ARID2, and KIAA2022) verified in our study were also mutated at a frequency greater than $5 \%$ in the COSMIC database. We also identified 9genes (ERBB4, ZNF721, NT5E, PDE10A, CA1, NUMB, NBN, ZFYVE16, and NCAM1) that were only mutated in metastasis and are expected to become treatment targets. In conclusion, we observed that the majority of the somatic mutations in the primary site persisted in metastasis, whereas several single-nucleotide polymorphisms occurred de novo at the second site.

\section{INTRODUCTION}

Gastric cancer is the fifth most commonly diagnosed cancer and the third leading cause of cancer mortality worldwide [1-3]. Although a steady decline in cancer incidence and mortality have been observed in recent years, an estimated 951,600 new gastric cancer cases and 723,100 deaths were reported in 2012. Approximately $40 \%$ of gastric cancer cases occur in China, and many are diagnosed at an advanced stage with a tendency toward metastasis and recurrence [4]. Peritoneal carcinoma occurs in both the advanced and early stages of gastric cancer and is the most common type of metastasis and recurrence [5-7]. The median survival of patients with peritoneal metastasis is less than 6 months due to the development of resistance to therapy [8-11]. Peritoneal metastasis accounts for $20.0-53.5 \%$ of recurrences after radical resection for gastric cancer [12]. Elucidating the molecular mechanism driving peritoneal metastasis of gastric adenocarcinoma is thus critical.

Next-generation sequencing has emerged as a powerful tool to identify potential oncogene targets for personal therapeutic intervention as part of precision medicine and has revolutionized cancer research $[13,14]$. 
Whole-genome sequencing provides a relatively unbiased review of the genome but is costly and produces large datasets, which present a heavy computational burden. Thus, many researchers and clinicians choose wholeexome sequencing (WES) for personal management [15]. WES directly sequences all exonic regions, which account for only $1 \%$ of the whole genome, to accurately depict the relationship between mutations and phenotypes. Furthermore, WES can achieve higher sequencing depth at a lower cost than whole-genome sequencing [16, 17]. In the era of precision medicine, WES is approved to facilitate the identification of candidate predictive biomarkers of response in metastatic cancer harboring biologically informative alterations [18].

Gastric adenocarcinoma is the most common type of gastric cancer. Once peritoneal metastasis is observed, surgery is no longer preferred as the therapeutic strategy, leading to difficulty in collecting matched primary and metastatic tumor specimens and a lack of relevant reports. $\mathrm{Xia}$ and colleagues recently suggested that non-curative dissection of peritoneal metastasis in selected gastric cancer patients significantly prolongs survival $[19,20]$. Accordingly, we collected matched specimens for WES after non-curative dissection [21]. The genomic events during gastric cancer dissemination to the peritoneum are unknown. In our study, we aimed to reveal the mutation spectrum of peritoneal metastatic gastric adenocarcinoma by WES. Normal gastric mucosa, primary cancer, normal peritoneum and peritoneal metastasis tissues were collected from one patient.

\section{RESULTS}

\section{Identification of single-nucleotide variants (SNVs) and insertions/deletions (INDELs) in primary and secondary tumor sites}

We identified 46,609 SNVs and 48,215 SNVs in the primary gastric cancer and peritoneal metastasis, respectively; approximately $89 \%$ of the SNVs had been detected by the 1000 Genomes Project. Additionally, 4,506 INDELs and 4,643 INDELs were identified in the primary gastric cancer and peritoneal metastasis, respectively, of which $43 \%$ had been identified by the 1000 Genomes Project. Even the normal gastric mucosa and peritoneum had many SNVs and INDELs. Most of the INDELs were less than five bases in length; small INDELs represent previous in-frame shift mutations (Figure 1).

\section{Identification of somatic variations from primary gastric cancer and peritoneal metastasis}

By comparing the normal gastric mucosa and peritoneal tissue, we identified 48 non-synonymous somatic mutations in the primary tumor and 49 nonsynonymous somatic mutations in the peritoneal metastasis after filtering, including7 somatic INDELs in the primary gastric cancer and 11 somatic INDELs in the secondary carcinoma. In the primary gastric adenocarcinoma, most (gastric adenocarcinoma vs. peritoneal nodules: $39 \%$ vs. $40 \%$, respectively) of the on-target somatic

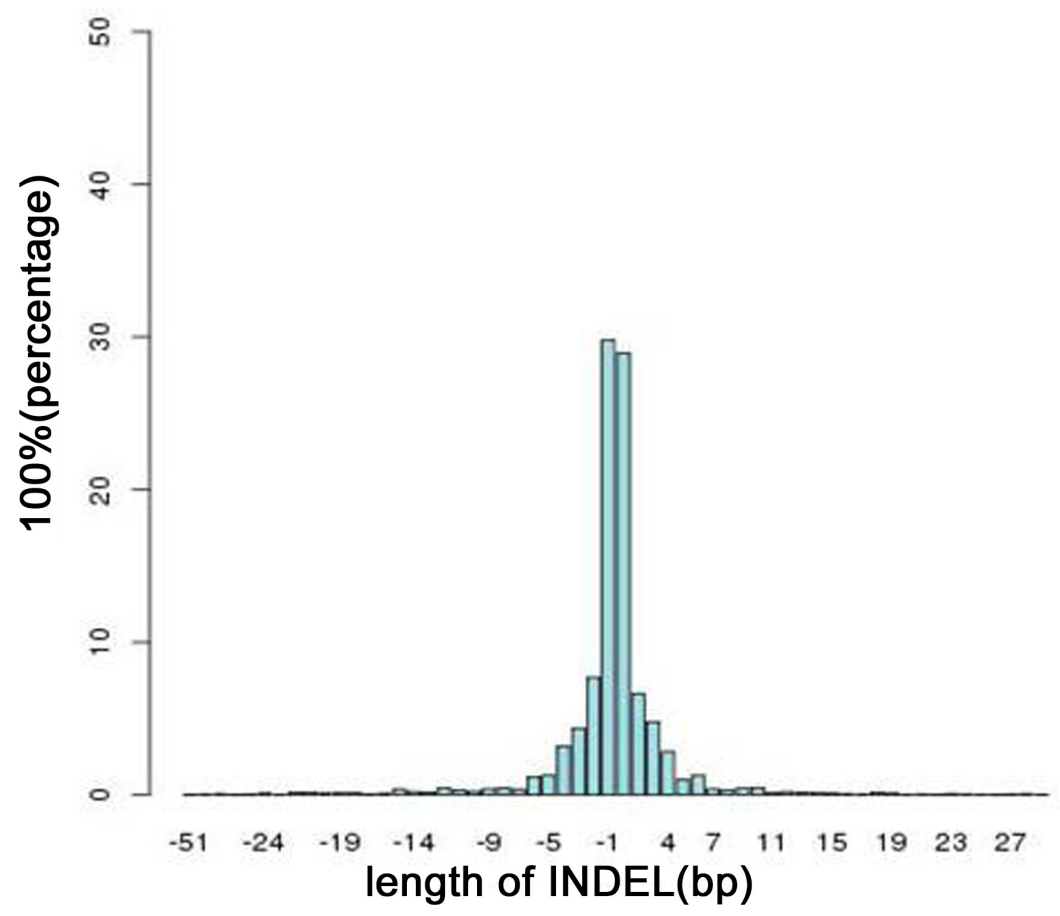

Figure 1: Distribution of the lengths of all INDELs in the on-target regions. A length $>0$ indicates an insertion mutation; otherwise, the length represents a deletion mutation. 
mutations were in the exonic region, and most (gastric adenocarcinoma vs. peritoneal nodules: $20 \%$ vs. $20 \% \%$, respectively) were synonymous somatic mutations. The primary gastric cancer and peritoneal metastasis exhibited similar mutation spectra. We observed that $\mathrm{G}: \mathrm{C}>\mathrm{A}$ : $\mathrm{T}$ was the most frequent transversion in somatic mutations (Figure 2). The transversion of $\mathrm{C}$ : $\mathrm{G}>\mathrm{T}$ : $\mathrm{A}$ was also enriched in the somatic mutations, consistent with a report by Chen et al. [14].

\section{Confirmation of somatic non-synonymous mutations}

Twenty-five non-synonymous somatic SNVs and 2 somatic INDELs were confirmed in the primary tumor (Table 1), and thirty non-synonymous SNVs and five INDELs were verified in the peritoneal metastasis (Table 2) (Figure 3). Approximately 59\% of the somatic mutations were shared between the primary and metastatic sites (Figure 4). The 22 mutated genes in common were IGFN1, NRXN1, CHL1, OR2W1, BAI1, RAG1, OR5T1, CPSF7, ARID2, THSD1, VWA3A, ZC2HC1C, C15orf57, TP53, ENOSF1, NDC80, MIER2, POLRMT, TTC3, KIAA2022, DNAJC3, and E2F7. Wealso identified nine genes (ERBB4, ZNF721, NT5E, PDE10A, CA1, NUMB, NBN, ZFYVE16, and NCAM1) that were only mutated in metastasis. Searching the KEGG PATHWAY database revealed that two genes (TP53 and BAI) that are important members of theTP53 pathway were simultaneously mutated in the gastric cancer and peritoneal metastasis. Both tumor sites also harbored two somatic non-synonymous mutations in the TP53 gene.

\section{Comparison with a public database}

In the COSMIC database, the most common type of substitutional somatic mutation in gastric adenocarcinoma is the transversion of $\mathrm{G}: \mathrm{C}>\mathrm{A}: \mathrm{T}$, and the major INDELs are short(less than 5 bases), consistent with our observations of the gastric adenocarcinoma with peritoneal metastasis in the present study. Five genes (TP53, BAI1, THSD1, ARID2, and KIAA2022 ) verified in our study were also mutated at a frequency greater than 5\% in gastric adenocarcinoma in the COSMIC database, but the amino acid changes F567L in ARID2, D76E in BAI1, L21I in THSD1, and D955H in KIAA2022 had not been reported previously in gastric cancer. In the COSMIC database, TP53 was mutated in $33.4 \%$ of gastric adenocarcinoma, and 2 point mutations in TP53 were identified in the present study. The ARID2 gene was mutated at a frequency of $5.3 \%$ in 514 gastric adenocarcinoma cases. In our study, the patient also had an ARID2 gene missense mutation in both the primary tumor and peritoneal metastasis. The mutation of BAI1 leads to the amino acid mutation L21T and exerts a damaging effect on its function. BAI1 was mutated in approximately $5 \%$ of gastric adenocarcinoma in the COSMIC database, and this angiogenesis inhibitor gene was even mutated as highly as $11 \%$ among the 295 samples reported in The Cancer Genome Atlas Research Network.THSD1, which is mutated in both the primary gastric cancer and peritoneal metastasis, has a mutation frequency of $5.4 \%(21 / 389)$ in gastric adenocarcinoma in the COSMIC database. KIAA2022 was mutated at a high frequency of $6.9 \%(27 / 389)$ as analyzed by the COSMIC database. In our study, we identified a missense somatic mutation in KIAA2022, and the consequent amino acid variationD955H would presumably exert a damaging effect in the protein (Figure 5).

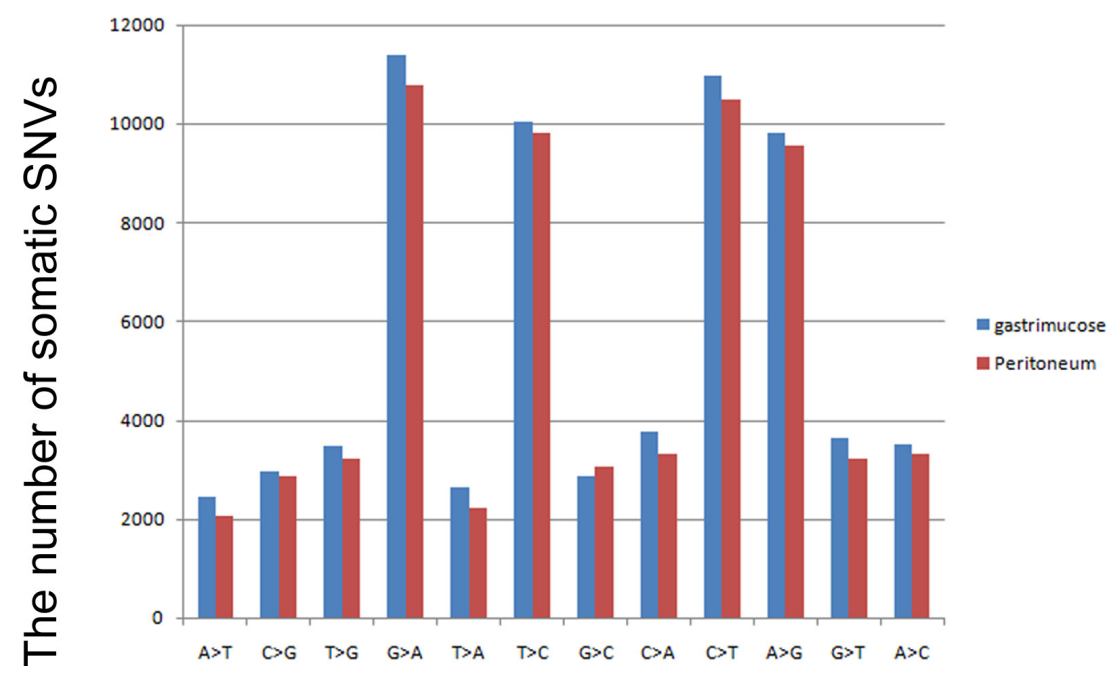

Figure 2: Mutation spectrum of non-synonymous variations in gastric cancer. The blue bar represents somatic mutations in primary gastric cancer, and the red bar indicates somatic non-synonymous mutations identified in peritoneal metastasis. 
Table 1: Somatic mutations identified by WES in primary gastric cancer

\begin{tabular}{|c|c|c|c|c|c|c|c|c|}
\hline Chr & Position & Exon & Allele change & $\begin{array}{l}\text { Amino acid } \\
\text { variation }\end{array}$ & Certification & Gene & db SNP & $\begin{array}{l}\text { Polyphen } 2 \\
\text { prediction }\end{array}$ \\
\hline chr14 & 75537380 & exon2 & $\mathrm{A}>\mathrm{G}$ & Y35C & $\mathrm{Y}$ & ZC2HC1C & - & Benign \\
\hline $\operatorname{chr} 15$ & 40846283 & exon4 & $\mathrm{C}>\mathrm{A}$ & A158S & $\mathrm{Y}$ & C15orf57 & - & Damaging \\
\hline chr1 & 111957501 & exon11 & $24 b p$ del & 533_541del & $\mathrm{N}$ & OVGP1 & rs201350653 & - \\
\hline $\operatorname{chr} 2$ & 179582678 & exon83 & $\mathrm{A}>\mathrm{G}$ & V7108A & $\mathrm{N}$ & TTN & - & Benign \\
\hline $\operatorname{chr} 17$ & 7574026 & exon6 & $\mathrm{C}>\mathrm{A}$ & G202V & $\mathrm{Y}$ & TP53 & - & Damaging \\
\hline $\operatorname{chr} 17$ & 7574027 & exon6 & $\mathrm{C}>\mathrm{A}$ & G202W & $\mathrm{Y}$ & TP53 & - & Damaging \\
\hline chr19 & 9057778 & exon3 & $\mathrm{A}>\mathrm{C}$ & S9890A & $\mathrm{N}$ & MUC16 & - & $\begin{array}{l}\text { Probably } \\
\text { damaging }\end{array}$ \\
\hline $\operatorname{chr} 1$ & 103481225 & exon10 & $\mathrm{G}>\mathrm{A}$ & P380L & $\mathrm{N}$ & COL11A1 & - & Damaging \\
\hline $\operatorname{chr} 2$ & 212248608 & exon27 & $\mathrm{T}>\mathrm{C}$ & E1204G & $\mathrm{N}$ & ERBB4 & - & $\begin{array}{l}\text { Probably } \\
\text { damaging }\end{array}$ \\
\hline $\operatorname{chr} 17$ & 10427078 & exon36 & $\mathrm{C}>\mathrm{G}$ & $\mathrm{D} 1767 \mathrm{H}$ & $\mathrm{N}$ & MYH2 & - & Damaging \\
\hline $\operatorname{chr} 3$ & 77684050 & exon24 & $\mathrm{C}>\mathrm{G}$ & R1264G & $\mathrm{Y}$ & ROBO2 & - & Benign \\
\hline $\operatorname{chrX}$ & 73961529 & exon3 & $\mathrm{C}>\mathrm{G}$ & D955H & $\mathrm{Y}$ & KIAA2022 & - & Damaging \\
\hline $\operatorname{chr} 1$ & 235926118 & exon22 & $\mathrm{A}>\mathrm{T}$ & $\mathrm{I} 2052 \mathrm{~N}$ & $\mathrm{Y}$ & LYST & - & $\begin{array}{l}\text { Probably } \\
\text { damaging }\end{array}$ \\
\hline $\operatorname{chr} 12$ & 46242737 & exon13 & $\mathrm{T}>\mathrm{C}$ & F567L & $\mathrm{Y}$ & ARID2 & - & Damaging \\
\hline $\operatorname{chr} 3$ & 30691871 & exon3 & $1 \mathrm{bp}$ ins & $\mathrm{E} 125 \mathrm{fs}$ & $\mathrm{N}$ & TGFBR2 & - & - \\
\hline $\operatorname{chr} 13$ & 52972327 & exon3 & $\mathrm{G}>\mathrm{T}$ & L21I & $\mathrm{Y}$ & THSD1 & - & $\begin{array}{l}\text { Probably } \\
\text { damaging }\end{array}$ \\
\hline $\operatorname{chr} 8$ & 143545787 & exon 1 & $\mathrm{C}>\mathrm{A}$ & D76E & $\mathrm{Y}$ & BAI1 & - & Damaging \\
\hline $\operatorname{chr} 3$ & 439979 & exon24 & $\mathrm{C}>\mathrm{G}$ & P1039R & $\mathrm{Y}$ & CHL1 & - & Damaging \\
\hline chr1 & 38185137 & exon 15 & $\mathrm{~T}>\mathrm{A}$ & K902M & $\mathrm{N}$ & EPHA10 & & Damaging \\
\hline $\operatorname{chr} 2$ & 50280649 & exon4 & $\mathrm{C}>\mathrm{A}$ & Q231H & $\mathrm{Y}$ & NRXN1 & - & Damaging \\
\hline chr11 & 36595492 & exon2 & $\mathrm{T}>\mathrm{C}$ & $\mathrm{I} 213 \mathrm{~T}$ & $\mathrm{Y}$ & RAG1 & - & Benign \\
\hline $\operatorname{chr} 12$ & 77449826 & exon3 & $1 \mathrm{bp}$ ins & F60fs & $\mathrm{Y}$ & E2F7 & - & - \\
\hline $\operatorname{chr} 11$ & 36595553 & exon2 & $1 \mathrm{bp}$ ins & $\mathrm{S} 233 \mathrm{fs}$ & $\mathrm{N}$ & RAG1 & - & - \\
\hline $\operatorname{chr} 21$ & 38494232 & exon12 & $\mathrm{T}>\mathrm{C}$ & L339P & $\mathrm{Y}$ & TTC3 & - & Damaging \\
\hline $\operatorname{chr} 4$ & 6304013 & exon8 & $\mathrm{G}>\mathrm{G}$ & G831C & $\mathrm{N}$ & WFS1 & - & Damaging \\
\hline $\operatorname{chr} 11$ & 14880776 & exon13 & $\mathrm{C}>\mathrm{A}$ & A903E & $\mathrm{N}$ & PDE3B & - & Damaging \\
\hline $\operatorname{chr} 15$ & 23931941 & exon1 & $\mathrm{G}>\mathrm{C}$ & $\mathrm{R} 142 \mathrm{G}$ & $\mathrm{N}$ & $\mathrm{NDN}$ & - & $\begin{array}{l}\text { Probably } \\
\text { damaging }\end{array}$ \\
\hline chr6 & 165801813 & exon17 & $\mathrm{A}>\mathrm{C}$ & F596V & $\mathrm{N}$ & PDE10A & - & Damaging \\
\hline $\operatorname{chr} 1$ & 201168763 & exon7 & $\mathrm{C}>\mathrm{T}$ & R147W & $\mathrm{Y}$ & IGFN1 & - & - \\
\hline $\operatorname{chr} 5$ & 178392069 & exon5 & $\mathrm{G}>\mathrm{T}$ & G222W & $\mathrm{N}$ & ZNF454 & - & Damaging \\
\hline $\operatorname{chr} 22$ & 29885858 & exon4 & $18 b p$ del & 744_749del & $\mathrm{N}$ & NEFH & rs59890097 & - \\
\hline chr8 & 90958479 & exon13 & $1 \mathrm{bp}$ ins & K653fs & $\mathrm{N}$ & NBN & & - \\
\hline $\operatorname{chr11}$ & 56043937 & exon 1 & $\mathrm{~A}>\mathrm{C}$ & $\mathrm{S} 275 \mathrm{R}$ & $\mathrm{Y}$ & OR5T1 & - & Benign \\
\hline
\end{tabular}




\begin{tabular}{|c|c|c|c|c|c|c|c|c|}
\hline Chr & Position & Exon & Allele change & $\begin{array}{c}\text { Amino acid } \\
\text { variation }\end{array}$ & Certification & Gene & db SNP & $\begin{array}{l}\text { Polyphen2 } \\
\text { prediction }\end{array}$ \\
\hline chr19 & 620049 & exon12 & $\mathrm{G}>\mathrm{A}$ & A932V & $\mathrm{Y}$ & POLRMT & - & Damaging \\
\hline chr4 & 437571 & exon3 & $\mathrm{C}>\mathrm{G}$ & A229P & $\mathrm{N}$ & ZNF721 & - & $\begin{array}{l}\text { Probably } \\
\text { damaging }\end{array}$ \\
\hline $\operatorname{chr} 18$ & 697265 & exon3 & $\mathrm{A}>\mathrm{C}$ & L95R & $\mathrm{Y}$ & ENOSF1 & - & Damaging \\
\hline chr11 & 4936758 & exon1 & $\mathrm{C}>\mathrm{A}$ & G46C & $\mathrm{Y}$ & OR51G2 & - & Damaging \\
\hline $\operatorname{chr} 18$ & 2577827 & exon4 & $\mathrm{G}>\mathrm{A}$ & $\mathrm{D} 88 \mathrm{~N}$ & $\mathrm{Y}$ & NDC80 & - & Damaging \\
\hline chr19 & 308907 & exon11 & $\mathrm{C}>\mathrm{T}$ & G335S & $\mathrm{Y}$ & MIER2 & - & Damaging \\
\hline $\operatorname{chrX}$ & 142596888 & exon2 & $\mathrm{T}>\mathrm{G}$ & K61T & $\mathrm{N}$ & SPANXN3 & - & Benign \\
\hline chr13 & 96439336 & exon11 & 3 bp del & $429 \_429 \mathrm{del}$ & Y & DNAJC3 & - & - \\
\hline $\operatorname{chr} 16$ & 22111606 & exon4 & $\mathrm{T}>\mathrm{C}$ & L106S & Y & VWA3A & - & Damaging \\
\hline chr6 & 29012638 & exon1 & $\mathrm{C}>\mathrm{T}$ & M105I & Y & OR2W1 & - & $\begin{array}{l}\text { Probably } \\
\text { damaging }\end{array}$ \\
\hline chr16 & 88600174 & exon10 & $\mathrm{G}>\mathrm{A}$ & $\mathrm{R} 603 \mathrm{H}$ & $\mathrm{N}$ & ZFPM1 & - & Damaging \\
\hline chr14 & 73822447 & exon4 & $\mathrm{G}>\mathrm{A}$ & $\mathrm{R} 5 \mathrm{~W}$ & $\mathrm{~N}$ & NUMB & - & Damaging \\
\hline chr8 & 86241943 & exon6 & $\mathrm{T}>\mathrm{A}$ & E215V & $\mathrm{N}$ & CA1 & - & $\begin{array}{l}\text { Probably } \\
\text { damaging }\end{array}$ \\
\hline $\operatorname{chr} 5$ & 134910301 & exon3 & $\mathrm{C}>\mathrm{T}$ & R94H & Y & CXCL14 & rs 139612389 & Damaging \\
\hline chr11 & 61179326 & exon8 & $\mathrm{G}>\mathrm{A}$ & R390C & Y & CPSF7 & & Damaging \\
\hline
\end{tabular}

Table 2: somatic mutations identified by WES in secondary cancer site

\begin{tabular}{|c|c|c|c|c|c|c|c|c|}
\hline Chr & Position & Exon & $\begin{array}{l}\text { Allele } \\
\text { change }\end{array}$ & $\begin{array}{c}\text { Amino acid } \\
\text { variation }\end{array}$ & Certification & Gene & db SNP & $\begin{array}{l}\text { Polyphen2 } \\
\text { prediction }\end{array}$ \\
\hline $\operatorname{chr} 1$ & 38185137 & exon15 & $\mathrm{T}>\mathrm{A}$ & K902M & $\mathrm{N}$ & EPHA10 & & Damaging \\
\hline $\operatorname{chr} 1$ & 103481225 & exon10 & $\mathrm{G}>\mathrm{A}$ & $\mathrm{P} 380 \mathrm{~L}$ & $\mathrm{~N}$ & COL11A1 & & Damaging \\
\hline $\operatorname{chr} 1$ & 201168763 & exon7 & $\mathrm{C}>\mathrm{T}$ & R147W & Y & IGFN1 & & - \\
\hline $\operatorname{chr} 2$ & 237619910 & exon16 & $\mathrm{A}>\mathrm{T}$ & N496I & $\mathrm{Y}$ & RYR2 & & Benign \\
\hline $\operatorname{chr} 2$ & 50280649 & exon4 & $\mathrm{C}>\mathrm{A}$ & Q231H & $\mathrm{Y}$ & NRXN1 & & Benign \\
\hline chr2 & 179582678 & exon83 & $\mathrm{A}>\mathrm{G}$ & V7108A & $\mathrm{Y}$ & TTN & & Benign \\
\hline $\operatorname{chr} 3$ & 212248608 & exon27 & $\mathrm{T}>\mathrm{C}$ & E1204G & $\mathrm{Y}$ & ERBB4 & & Probably damaging \\
\hline $\operatorname{chr} 3$ & 439979 & exon24 & $\mathrm{C}>\mathrm{G}$ & P1039R & $\mathrm{Y}$ & CHL1 & & Damaging \\
\hline $\operatorname{chr} 4$ & 75786223 & exon5 & $\mathrm{A}>\mathrm{T}$ & F851I & $\mathrm{N}$ & ZNF717 & & Damaging \\
\hline $\operatorname{chr} 4$ & 437571 & exon3 & $\mathrm{C}>\mathrm{G}$ & A229P & $\mathrm{Y}$ & ZNF721 & & Probably damaging \\
\hline chr6 & 6304013 & exon8 & $\mathrm{G}>\mathrm{T}$ & G831C & $\mathrm{N}$ & WFS1 & & Damaging \\
\hline chr6 & 29012638 & exon1 & $\mathrm{C}>\mathrm{T}$ & M105I & Y & OR2W1 & & Probably damaging \\
\hline chr6 & 86199234 & exon6 & $\mathrm{C}>\mathrm{T}$ & $\mathrm{T} 376 \mathrm{M}$ & $\mathrm{Y}$ & NT5E & & Probably damaging \\
\hline chr8 & 165801813 & exon17 & $\mathrm{A}>\mathrm{C}$ & F596V & $\mathrm{Y}$ & PDE10A & & Damaging \\
\hline $\operatorname{chr} 8$ & 86241943 & exon6 & $\mathrm{T}>\mathrm{A}$ & $\mathrm{E} 215 \mathrm{~V}$ & $\mathrm{Y}$ & CA1 & & $\begin{array}{r}\text { Probably damaging } \\
\text { (Continued) }\end{array}$ \\
\hline
\end{tabular}




\begin{tabular}{|c|c|c|c|c|c|c|c|c|}
\hline Chr & Position & Exon & $\begin{array}{l}\text { Allele } \\
\text { change }\end{array}$ & $\begin{array}{l}\text { Amino acid } \\
\text { variation }\end{array}$ & Certification & Gene & db SNP & $\begin{array}{l}\text { Polyphen2 } \\
\text { prediction }\end{array}$ \\
\hline $\operatorname{chr} 11$ & 143545787 & exon1 & $\mathrm{C}>\mathrm{A}$ & $\mathrm{D} 76 \mathrm{E}$ & $\mathrm{Y}$ & BAI1 & & Damaging \\
\hline $\operatorname{chr} 11$ & 4936758 & exon1 & $\mathrm{C}>\mathrm{A}$ & G46C & $\mathrm{N}$ & OR51G2 & & Damaging \\
\hline $\operatorname{chr} 11$ & 36595492 & exon2 & $\mathrm{T}>\mathrm{C}$ & $\mathrm{I} 213 \mathrm{~T}$ & Y & RAG1 & & Benign \\
\hline $\operatorname{chr} 11$ & 56043937 & exon1 & $\mathrm{A}>\mathrm{C}$ & S275R & $\mathrm{Y}$ & OR5T1 & & Benign \\
\hline $\operatorname{chr} 12$ & 61179326 & exon8 & $\mathrm{G}>\mathrm{A}$ & R390C & $\mathrm{Y}$ & CPSF7 & & Damaging \\
\hline $\operatorname{chr} 13$ & 46242737 & exon13 & $\mathrm{T}>\mathrm{C}$ & F567L & $\mathrm{Y}$ & ARID2 & & Damaging \\
\hline $\operatorname{chr} 14$ & 52972327 & exon3 & $\mathrm{G}>\mathrm{T}$ & THSD1 & $\mathrm{Y}$ & THSD1 & & Probably damaging \\
\hline chr14 & 73822447 & exon4 & $\mathrm{G}>\mathrm{A}$ & $\mathrm{R} 5 \mathrm{~W}$ & $\mathrm{Y}$ & NUMB & & Damaging \\
\hline $\operatorname{chr} 15$ & 75537380 & exon2 & $A>G$ & Y35C & $\mathrm{Y}$ & $\mathrm{ZC} 2 \mathrm{HC} 1 \mathrm{C}$ & & Benign \\
\hline $\operatorname{chr} 16$ & 40846283 & exon4 & $\mathrm{C}>\mathrm{A}$ & A158S & $\mathrm{Y}$ & C15orf57 & & Damaging \\
\hline $\operatorname{chr} 16$ & 22111606 & exon4 & $\mathrm{T}>\mathrm{C}$ & L106S & $\mathrm{Y}$ & VWA3A & & Damaging \\
\hline $\operatorname{chr} 17$ & 88600174 & exon10 & $\mathrm{G}>\mathrm{A}$ & $\mathrm{R} 603 \mathrm{H}$ & $\mathrm{N}$ & ZFPM1 & & Damaging \\
\hline $\operatorname{chr} 17$ & 7574026 & exon6 & $\mathrm{C}>\mathrm{A}$ & G202V & $\mathrm{Y}$ & TP53 & & Damaging \\
\hline $\operatorname{chr} 17$ & 7574027 & exon6 & $\mathrm{C}>\mathrm{A}$ & G202W & $\mathrm{Y}$ & ТР53 & & Damaging \\
\hline $\operatorname{chr} 18$ & 697265 & exon3 & $\mathrm{A}>\mathrm{C}$ & L95R & $\mathrm{Y}$ & ENOSF1 & & Damaging \\
\hline $\operatorname{chr} 19$ & 2577827 & exon4 & $\mathrm{G}>\mathrm{A}$ & $\mathrm{D} 88 \mathrm{~N}$ & $\mathrm{Y}$ & NDC80 & & Damaging \\
\hline $\operatorname{chr} 19$ & 308907 & exon11 & $\mathrm{C}>\mathrm{T}$ & G335S & $\mathrm{Y}$ & MIER2 & & Damaging \\
\hline $\operatorname{chr} 19$ & 620049 & exon12 & $\mathrm{G}>\mathrm{A}$ & A932V & $\mathrm{Y}$ & POLRMT & & Damaging \\
\hline $\operatorname{chr} 21$ & 9057778 & exon3 & $\mathrm{A}>\mathrm{C}$ & S9890A & $\mathrm{N}$ & MUC16 & & Probably damaging \\
\hline $\operatorname{chr} 22$ & 38494232 & exon12 & $\mathrm{T}>\mathrm{C}$ & L339P & $\mathrm{Y}$ & TTC3 & & Damaging \\
\hline $\operatorname{chr} \mathrm{X}$ & 19119441 & exon1 & $\mathrm{G}>\mathrm{A}$ & G177R & $\mathrm{N}$ & TSSK2 & & Damaging \\
\hline $\operatorname{chrX}$ & 73961529 & exon7 & $\mathrm{C}>\mathrm{G}$ & D955H & $\mathrm{Y}$ & KIAA2022 & & Damaging \\
\hline chr3 & 142596888 & exon9 & $\mathrm{T}>\mathrm{G}$ & K61T & Y & SPANXN3 & & Benign \\
\hline $\operatorname{chr} 3$ & 30691871 & exon3 & 1 bp ins & E125fs & $\mathrm{N}$ & TGFBR2 & & - \\
\hline $\operatorname{chr} 12$ & 77449826 & exon3 & 1 bp ins & F60fs & $\mathrm{Y}$ & E2F7 & & - \\
\hline $\operatorname{chr} 13$ & 96439336 & exon11 & 3 bp del & $429 \_429 \mathrm{del}$ & $\mathrm{Y}$ & DNAJC3 & & - \\
\hline $\operatorname{chr} 11$ & 36595553 & exon2 & 1 bp ins & S233fs & $\mathrm{N}$ & RAG1 & & - \\
\hline chr8 & 90958479 & exon13 & $1 \mathrm{bp}$ ins & K653fs & $\mathrm{Y}$ & NBN & & - \\
\hline chr6 & 160211645 & exon1 & $3 b p$ del & 9_10del & $\mathrm{N}$ & MRPL18 & rs58504486 & - \\
\hline $\operatorname{chr} 5$ & 79746372 & exon9 & 4 bp del & 1117_1118del & $\mathrm{Y}$ & ZFYVE16 & & - \\
\hline $\operatorname{chr} 16$ & 70954703 & exon46 & $15 \mathrm{bp}$ del & 2521_2525del & $\mathrm{N}$ & HYDIN & rs67115747 & - \\
\hline $\operatorname{chr} 9$ & 139992321 & exon5 & 1 bp del & L221fs & $\mathrm{N}$ & MAN1B1 & & - \\
\hline chr11 & 112832362 & exon2 & $1 \mathrm{bp}$ del & $\mathrm{T} 10 \mathrm{fs}$ & $\mathrm{Y}$ & NCAM1 & & - \\
\hline $\operatorname{chr} 3$ & 75787042 & exon5 & 4 bp ins & L578fs & $\mathrm{N}$ & ZNF717 & & - \\
\hline
\end{tabular}




\section{DISCUSSION}

We performed WES to uncover the somatic mutation landscape of gastric adenocarcinoma with peritoneal metastasis. The mechanism of the peritoneal dissemination of gastric adenocarcinoma remains unknown, and there is no standard therapeutic method, resulting in poor survival [22]. Targeted gene analysis has identified TNF-alpha and EpCAM expression as facilitating peritoneal metastasis, whereas IL-1B might not correlate with the process of metastasis [23, 24].Catumaxomab, an anti-EpCAM monoclonal antibody, coupled with intraperitoneally administered paclitaxel are recommended to effectively relieve gastric cancer-derived peritoneal metastasis [25]. Zhang et al. recently identified 27 somatic mutated genes and infusion of GPX4 and MPND in the19q13.3-13.4 region by whole-genome and -transcriptome sequencing of one patient [4]. The different mutation events in the present study may be attributable to the different pathological characteristics of the selected specimen. However, we cannot neglect the errors resulting from the small number of specimens in these two studies. Lim et al revealed significant enrichment of mutations in the Rho-ROCK signaling pathway by WES of gastric cancer and matched malignant ascites [21]. The discrepancies between Lim's findings and our results may be due in part to the diversity in sample selection. Genomic alterations also accumulate during the process of metastasis. The heterogeneity of gastric cancer, as revealed by Bass AJ e al., may also underlie the differences between our results
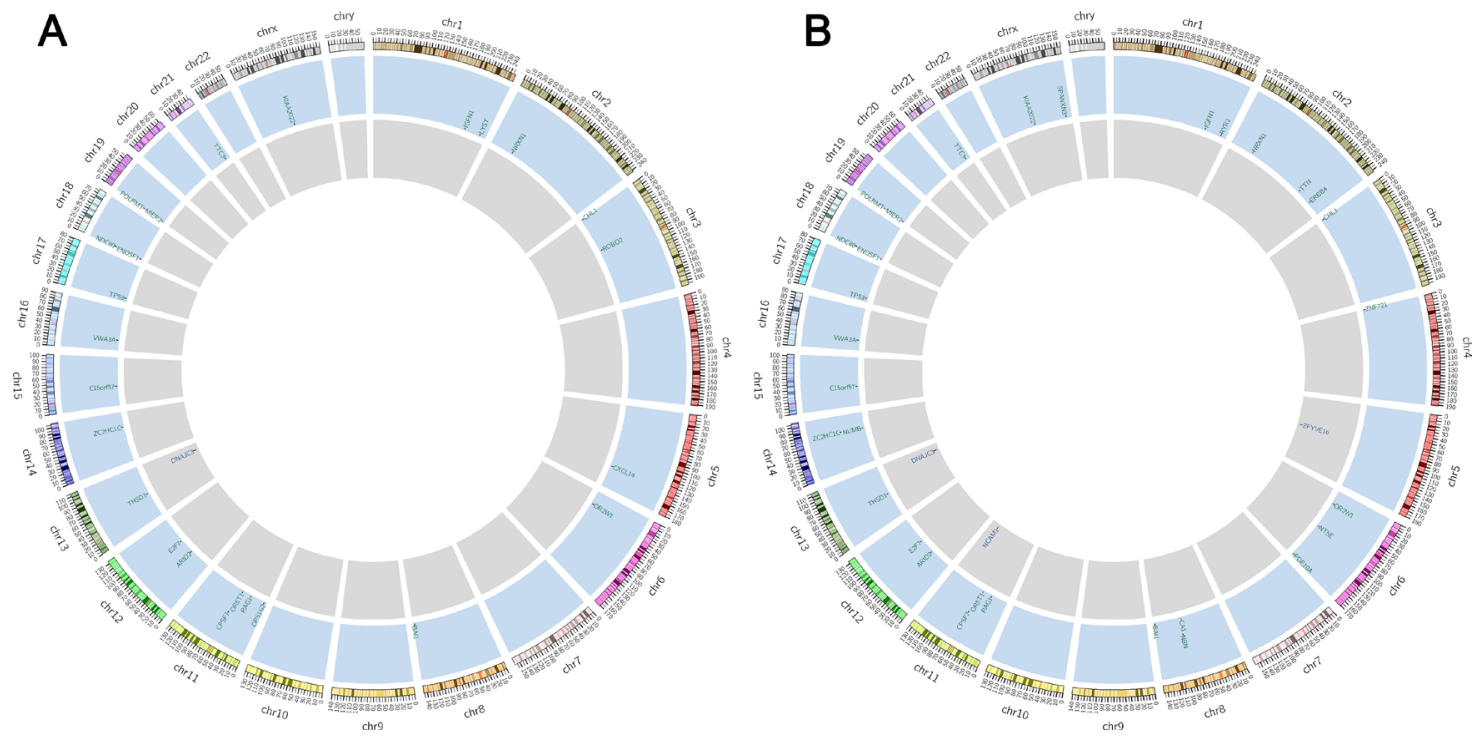

Figure 3: Non-synonymous somatic mutations discovered by WES. From outside to inside: the outer ring represents the chromosome number and section, the blue ring and letters indicate mutated genes with non-synonymous somatic variations and their chromosomal locations, and the gray ring shows genes with somatic INDEL mutations. Figure 3A and 3B summarize the confirmed nonsynonymous somatic mutations in primary gastric adenocarcinoma and peritoneal metastasis, respectively.

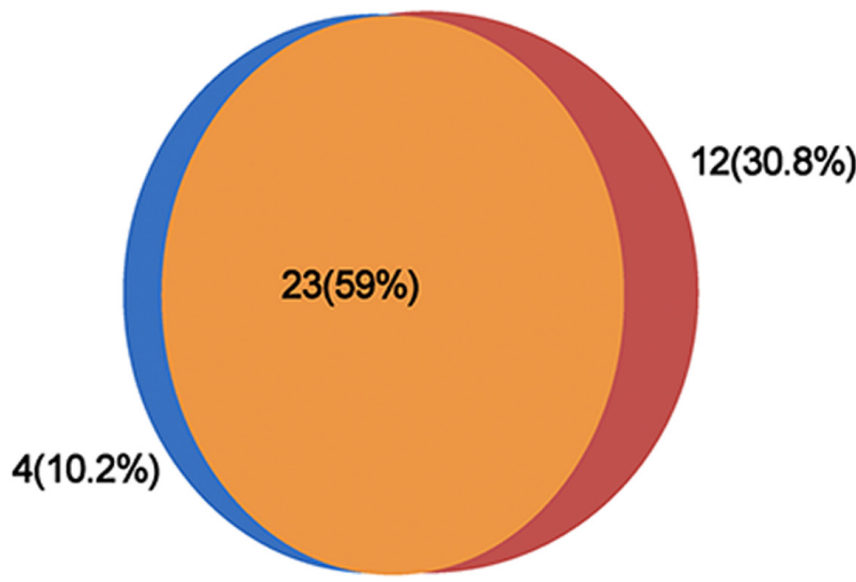

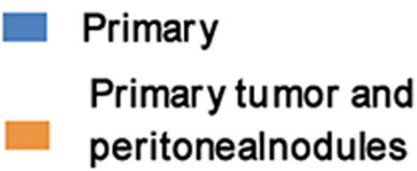

Peritonealnodules

Figure 4: Distribution of confirmed non-synonymous somatic mutations in primary gastric cancer and peritoneal metastasis. 
and those of other studies [26]. We confirmed 20 somatic SNVs and 2 INDELs in one gastric adenocarcinoma by WES. After searching the KEGG public database, we identified two genes in the p53 pathway. The spontaneous mutation of p53 and BAI1 might play a vital role in the development of peritoneal metastasis of gastric adenocarcinoma. Five genes (TP53, BAI1, ARID2, THSD1, and KIAA2022) mutated in primary cancer and nine genes (ERBB4, ZNF721, NT5E, PDE10A, CA1, NUMB, NBN, ZFYVE16, NCAM1) mutated in peritoneal metastasis may be targets for the effective treatment of peritoneal metastatic gastric adenocarcinoma.

Somatic mutations of BAI1 and its family members BAI2 and BAI3, which encode brain-specific angiogenesis inhibitors, have been identified in several cancers, including breast cancer, lung cancer, and ovarian cancer. Only BAI1 is transcriptionally regulated by p53 [27]. BAI1 is reported to be expressed in gastric epithelia during Helicobacter pylori infection and mediates the engulfment of apoptotic gastric epithelial cells [28]. BAI1 is also decreased in gastric cancer in patients with distant metastasis and poor prognosis [29]. Therefore, the role of BAI1 in metastatic gastric adenocarcinoma merits further study.

ARID2 is a subunit of the PBAF chromatinremodeling complex and has been reported to be mutated in melanoma (7\%) and colorectal cancer (13\%). ARID2 has been suggested to be tumor suppressive in hepatocellular carcinoma, with a mutation rate of $6.5 \%$. ARID2 is mutated in $13 \%$ of colorectal cancer patients with microsatellite instability [30]. ARID2is also mutated in $18.2 \%$ of hepatocellular carcinoma cases, leading to inactivation of the coding protein [31]. Furthermore, the expression of ARID2 and its family members is lost during gastric cancer progression, but the effect of ARID2 on tumor progression is weaker than that of ARID1A [32]. In our study, ARID2 was synonymously mutated in exon 13 and putatively disrupted the protein's function.

THSD1 is located in the chromosome $13 \mathrm{q}$ region that is frequently lost in esophageal cancer, accelerating cancer formation [33]. In the COSMIC database, THSD1 was mutated in 5.4\% (21/389) of gastric adenocarcinoma. In colorectal cancer, THSD1 is down-regulated and methylated in the promoter region [34], but the expression of THSD1 in gastric cancer with peritoneal metastasis and its role in turmorigenesis are not yet known. The THSD1 mutation in exon 3 observed in this study results in the amino acid change L21T, likely exerts a damaging effect on the protein's function.

KIAA2022 is a G-protein-coupled purinergic receptor gene located in the pseudoautosomal region
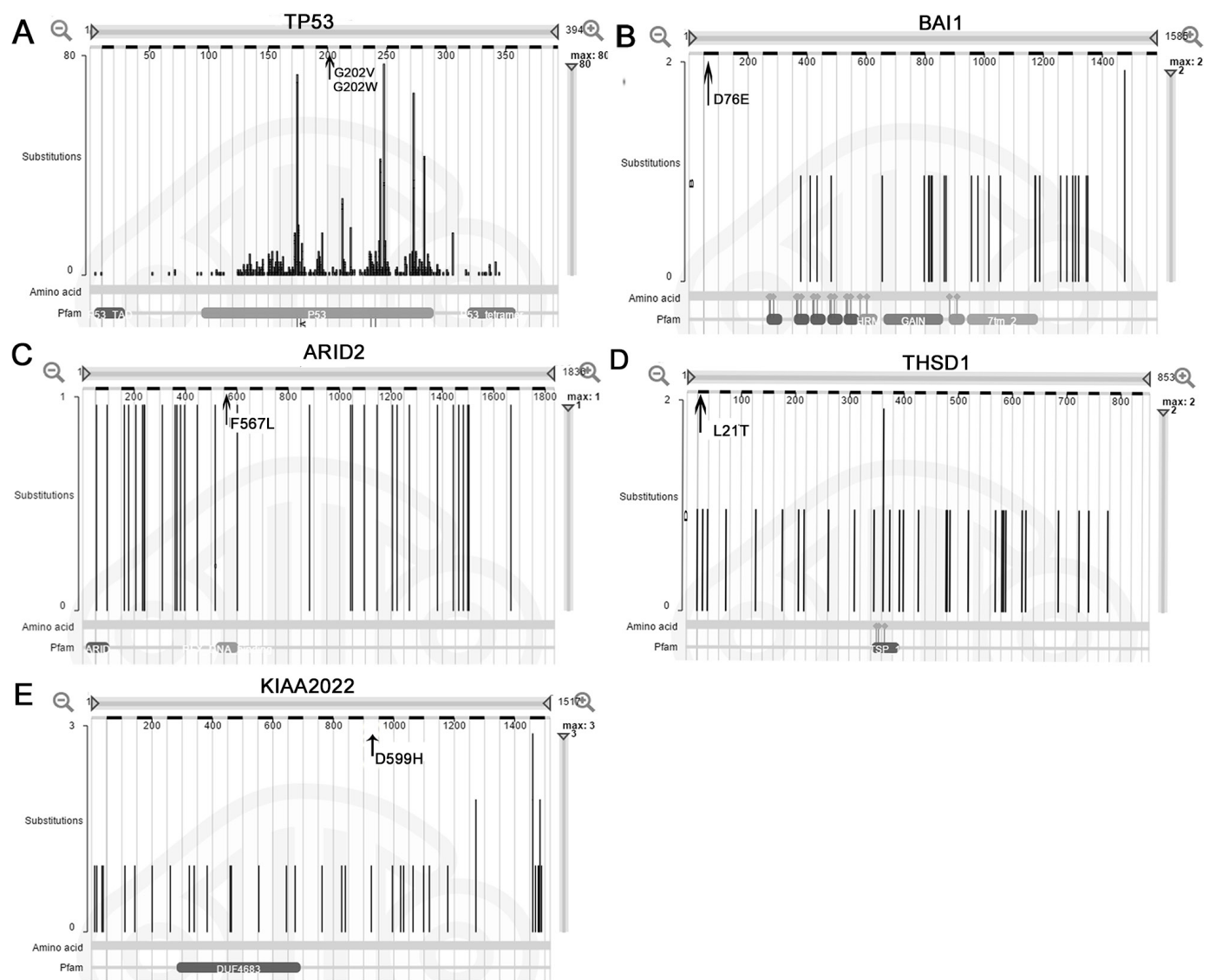

Figure 5: Mutation distribution of the five genes in the COSMIC database. A, B, C, D, and E represent the genesTP53, BAI1, ARID2, THSD1 and KIAA2022, respectively. The arrow indicates the site of the mutation identified in gastric adenocarcinoma and matched peritoneal metastasis. 
of the X chromosome. For gastric adenocarcinoma, theKIAA2022 gene is mutated at a high frequency of $6.9 \%(27 / 389)$ in the COSMIC database. ZC2HC1C and $\mathrm{C} 15$ orf57 were mutated in both the primary gastric cancer tissue and peritoneal metastasis and identified in gastric cancer for the first time. The mutation inZC2HC1C was an $A>G$ substitution in exon 2, leading to a putatively benign effect, whereas the C15orf57 somatic mutation likely exerted a damaging effect on the protein.

Nine genes were mutated in the peritoneal metastasis: ERBB4, ZNF721, NT5E, PDE10A, CA1, NUMB, NBN, ZFYVE16, and NCAMI. The acquisition of somatic mutations in these genes after metastasis, may drive phenotypic changes in cancer cells and the metastasis of gastric adenocarcinoma. As a member of the EGFR family, ERBB4 is frequently activated in brain metastases and metastatic colorectal cancer [35, 36]. In breast cancer, ERBB4plays an important role in the survival of ERBB2+ cells after they acquire resistance to lapatinib and trastuzumab [37]. The druggable gene ERBB4 was also reported to be mutated in malignant ascites of patients with gastric cancer [21]. We identified a somatic mutation in ERBB4 that may exert a damaging effect. Whether ERBB4 is indispensable for facilitating the peritoneal metastasis of gastric adenocarcinoma requires further investigation. The NUMB protein participates in the control of asymmetric division, ubiquitination of transcriptional factor $\mathrm{p} 53$, and endocytosis of the Notch receptor, and NUMB mutation leads to several types of cancer [38, 39]. We will further investigate the role of NUMB in peritoneal metastatic gastric cancer in a future study. The effects of somatic mutations in genes encoding zinc finger proteins (ZNF721 and ZFYVE16), a purine and pyrimidine metabolism protein (NT5E), carbonic anhydrase(CA1), and cyclic nucleotide phosphodiesterase(PDE10A)on the progress of gastric cancer requires further study.NCAM1, also known as cell adhesion molecular CD56, plays an important role in immune surveillance for the expansion of $\mathrm{T}$ cells, andNCAM1 over-expression in Ewing sarcoma indicates poor prognosis [40]. An insertion mutation was validated in the DNA repair gene NBN, which is altered in high-risk breast cancer [41]. Zhou et al. reported that polymorphic NBN tended to improve chemotherapeutic outcomes in gastric cancer. Because DNA repair capacity is attenuated during the evolution of cancer, more phenotypic changes tend to accelerate the formation of metastasis.

In summary, we performed WES of a gastric adenocarcinoma with peritoneal metastasis. Five genes (TP53, BAI1, THSD1, ARID2, and KIAA2022) identified as frequently mutated in the COSMIC database may drive gastric adenocarcinoma dissemination to the peritoneum. The effect of the two novel somatic mutated genes (ZC2HC1C and C15orf57) in gastric cancer requires further investigation. Nine genes (ERBB4, ZNF721, NT5E, PDE10A, CA1, NUMB, NBN, ZFYVE16, and NCAMI) mutated in peritoneal metastasis are potential molecular targets for the treatment of metastatic gastric cancer. The major limitations of our study are the small sample size and single sequencing platform.

\section{MATERIALS AND METHODS}

\section{Clinicopathology of the patient}

The 60-year-old male patient was diagnosed with gastric cancer with peritoneal metastasis by computed tomography (CT) and gastroscope inspection at Nanfang Hospital of Southern Medical University in 2014. The patient had not received preoperative chemotherapy or radiotherapy; he underwent palliative total gastrectomy and D2-NO.10 lymphadenectomy followed by the construction of Roux-en-Y esophagojejunostomy. After surgery, the specimens were subjected to further pathological testing, which revealed poorly differentiated primary gastric adenocarcinoma located in the cardia of the stomach of Borrmann III type with a maximum diameter of $5 \mathrm{~cm}$. Furthermore, the gastric tumor was of the mixed type in Lauren classification and had invaded to the submucosa. Lymphatic metastasis was also confirmed $(8 / 63)$. Thus, the patient had advanced gastric cancer with a dismal prognosis. Sample collection and sequencing analysis were approved by the ethics committee of Southern Medical University, and the patient provided written informed consent.

\section{Sample collection and DNA extraction}

We harvested matched gastric cancer tissue and adjacent normal gastric mucosa, peritoneal metastasis and adjacent normal peritoneal tissue from one patient by laparoscopy. The DNeasy Blood \& Tissue Kit (Qiagen, Germany) was used according to the manufacturer's instructions to extract and purify DNA from the harvested tissues. The concentration and quality of the DNA were determined using a NanoDrop ND-1000 spectrophotometer. Finally, 0.8\%agarose gel electrophoresis was performed to confirm the quality of the DNA. Four DNA samples passed all of the strict quality supervision tests and were available for WES.

\section{Whole-exome capture}

We selected IlluminaHiSeq 2500in a paired end $2 \times 100$ nt multiplex procedure to capture all exons of the samples. First, we constructed a DNA library by fragmenting the genomic DNA. Second, we utilized a Qubit $^{\circledR}$ 2.0 Fluorometer to determine the concentration of the library, and the Agilent 2100 system was used to investigate the library's quality. Next, we utilized the Illumina PE Flow Cell v3 - HS system to sequence randomized DNA fragments. All sequencing processes were controlled by data collection software according to the HiSeq 2500 User Guide. 


\section{Analysis of raw sequencing data}

We aligned the paired-end reads to the reference human genome (hg19) using the third-party software BWA (Burrows-Wheeler Alignment, version5.9) with default parameters for the deletion of possible PCR repeats by samtools rmdup. The average mapping ratio was as high as $96 \%$. The Flagstat tool was utilized to assess the mapping information. Next, we analyzed the distribution of each sample's reads in the target region and the enrichment of reads in the genome. The average sequencing depth in the exome region of the case was approximately $100 \times$; under these conditions, at least $90 \%$ of the exome region was covered by 10 or more reads, and the coverage of the target region was approximately $80 \%$ (Supplementary Figure S1). SNVs (single nucleotide variations) and INDELs (insert and deletion mutations) were then processed using the GATK UnifiedGenotyper
(GenomeAnalysisTK-3.1-1). Finally, we annotated the mutations using ANNOVAR software.

\section{Identification of somatic SNV and INDEL mutations}

We applied MuTect to the WES data to detect somatic point and INDEL mutations. Normal gastric mucosa tissue and peritoneum tissue were used as references for somatic mutations of the primary and secondary tumors, respectively. Low-quality reads were first removed, bam was performed for alignment by GATK INDEL and SNV realigner after eliminating possible duplicates, and MuTect was then used to identify somatic SNVs. All somatic SNVs were annotated by ANNOVAR, which annotates by gene symbol, chromosome position, reference bases and observed bases, and mutation type. By filtering false positives, confident somatic SNVs were obtained (Figure 6).

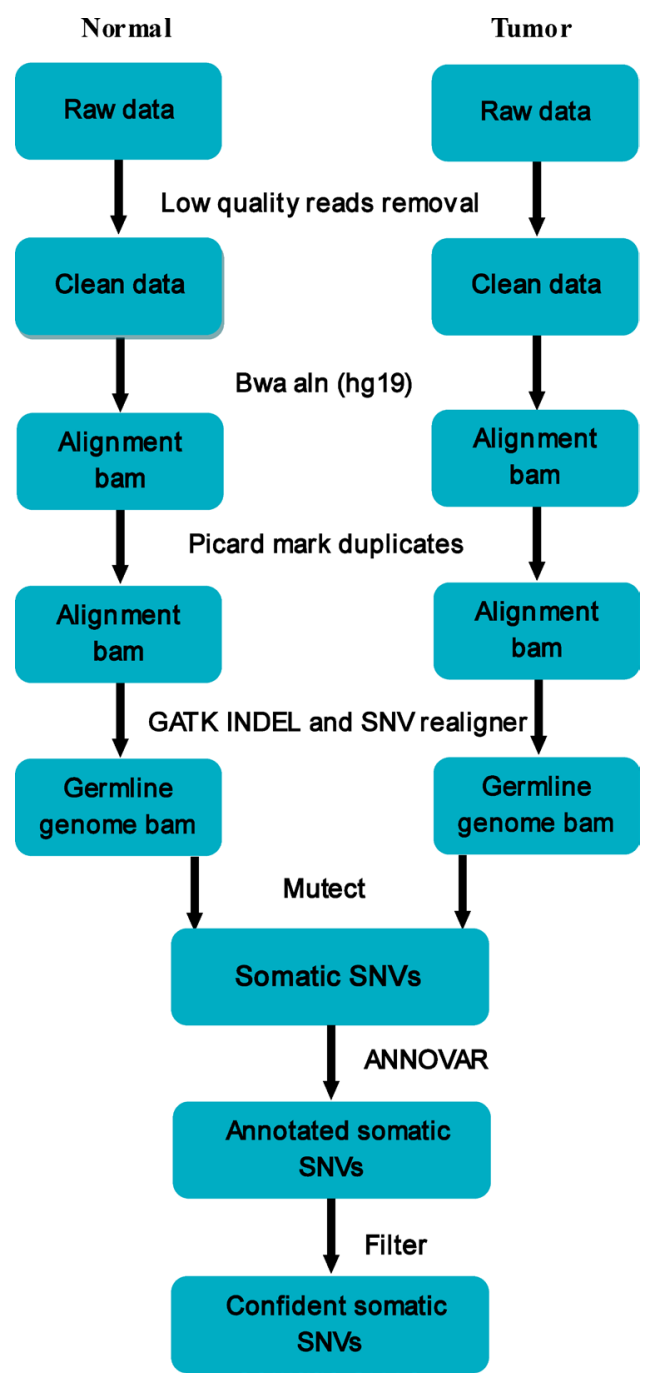

Figure 6: Pipeline of somatic mutation analysis from raw sequencing data. Low-quality reads were removed, and bam was performed for alignment using GATK INDEL and SNV realigner after eliminating possible duplicates. MuTectwas used to identify somatic SNVs, and all somatic SNVs were annotated by ANNOVAR. By filtering false positives, confident somatic SNVs were obtained. 


\section{Confirmation of non-synonymous somatic mutations}

We exploited the Verity 96-well PCRamplifier(ABI, USA) to perform PCR by adding special primers, followed by conventional PCR-based Sanger sequencing using the ABI3730XL(ABI, USA) sequencer, the gold standard of sequencing systems. Next, we compared the results with the next-generation sequencing data to confirm the nonsynonymous somatic mutations.

\section{Comparison with a public database}

COSMIC V76 is the latest version of the database of the catalog of somatic mutations in cancer. The database includes 1, 192,776 tumor samples for sequencing and25, 133whole-genome sequencing projects that have identified 3,942,175 coding mutations. Most of the data have been imported from the TCGA and ICGC databases. We compared our somatic mutations with the COSMIC database to identify driver genes of gastric cancer with peritoneal metastasis.

\section{ACKNOWLEDGMENTS}

We thank the professionals from Shanghai Biotechnology Corporation, Shanghai, China for sequencing and assisting our data analysis.

\section{CONFLICTS OF INTEREST}

The authors declare no conflicts of interest.

\section{GRANT SUPPORT}

This work was supported by the Guangdong Provincial Science and Technology Project (No.2014A020215014); the Research Fund of Public Welfare in Health Industry, National Health and Family Planning Commission of China (No. 201402015); the Key Clinical Specialty Discipline Construction Program, Foundation for Distinguished Young Talents in Higher Education of Guangdong, China (No. 2013LYM_0006); and the Scientific Research Foundation for Returned Scholars ( $48^{\text {th }}$ series), Ministry of Education, China.

\section{REFERENCES}

1. McLean MH, El-Omar EM. Genetics of gastric cancer. Nat Rev Gastroenterol Hepatol. 2014; 11:664-674.

2. Torre LA, Bray F, Siegel RL, Ferlay J, Lortet-Tieulent J, Jemal A. Global cancer statistics, 2012. CA Cancer J Clin. 2015; 65:87-108.

3. Hu Y, Huang C, Sun Y, Su X, Cao H, Hu J, Xue Y, Suo J, Tao K, He X, Wei H, Ying M, Hu W, et al. Morbidity and mortality of laparoscopic versus open D2 distal gastrectomy for advanced gastric cancer: a randomized controlled trial. J Clin Oncol. 2016; 34:1350-1357.

4. Zhang J, Huang JY, Chen YN, Yuan F, Zhang H, Yan FH, Wang MJ, Wang G, Su M, Lu G, Huang Y, Dai H, Ji J, et al. Whole genome and transcriptome sequencing of matched primary and peritoneal metastatic gastric carcinoma. Sci Rep. 2015; 5:13750.

5. Huang B, Sun Z, Wang Z, Lu C, Xing C, Zhao B, Xu H. Factors associated with peritoneal metastasis in nonserosa-invasive gastric cancer: a retrospective study of a prospectively-collected database. BMC Cancer. 2013; 13:57.

6. Kerkar SP, Kemp CD, Duffy A, Kammula US, Schrump DS, Kwong KF, Quezado M, Goldspiel BR, Venkatesan A, Berger A, Walker M, Toomey MA, Steinberg SM, et al. The GYMSSA trial: a prospective randomized trial comparing gastrectomy, metastasectomy plus systemic therapy versus systemic therapy alone. Trials. 2009; 10:121.

7. Kodera Y, Yamamura Y, Shimizu Y, Torii A, Hirai T, Yasui K, Morimoto T, Kato T. Peritoneal washing cytology: prognostic value of positive findings in patients with gastric carcinoma undergoing a potentially curative resection. J Surg Oncol. 1999; 72:60-64.

8. Yonemura Y, Bandou E, Kinoshita K, Kawamura T, Takahashi S, Endou Y, Sasaki T. Effective therapy for peritoneal dissemination in gastric cancer. Surg Oncol Clin N Am. 2003; 12:635-648.

9. Wu SM, Lin WY, Shen CC, Pan HC, Keh-Bin W, Chen YC, Jan YJ, Lai DW, Tang SC, Tien HR, Chiu CS, Tsai TC, Lai YL, et al. Melatonin set out to ER stress signaling thwarts epithelial mesenchymal transition and peritoneal dissemination via calpain-mediated C/EBPbeta and NFkappaB cleavage. J Pineal Res. 2016; 60:142-154.

10. Roviello F, Marrelli D, de Manzoni G, Morgagni P, Di Leo A, Saragoni L, De Stefano A, Italian Research Group for Gastric Cancer. Prospective study of peritoneal recurrence after curative surgery for gastric cancer. Br J Surg. 2003; 90:1113-1119.

11. Shah MA. Update on metastatic gastric and esophageal cancers. J Clin Oncol. 2015; 33:1760-1769.

12. Inoue $K$, Nakane $Y$, Michiura $T$, Nakai K, Sato M, Okumura S, Yamamichi K, Okamura S, Imabayashi N. Trends in long-term survival following surgery for gastric cancer: a single institution experience. Oncol Rep. 2004; 11:459-464.

13. Lin $\mathrm{Y}, \mathrm{Wu} \mathrm{Z}$, Guo W, Li J. Gene mutations in gastric cancer: a review of recent next-generation sequencing studies. Tumour Biol. 2015; 36:7385-7394.

14. Chen K, Yang D, Li X, Sun B, Song F, Cao W, Brat DJ, Gao Z, Li H, Liang H, Zhao Y, Zheng H, Li M, et al. Mutational landscape of gastric adenocarcinoma in Chinese: implications for prognosis and therapy. Proc Natl Acad Sci U S A. 2015; 112:1107-1112. 
15. LeBlanc VG, Marra MA. Next-generation sequencing approaches in cancer: Where have they brought us and where will they take us? Cancers (Basel). 2015; 7:1925-1958.

16. Ng SB, Turner EH, Robertson PD, Flygare SD, Bigham AW, Lee C, Shaffer T, Wong M, Bhattacharjee A, Eichler EE, Bamshad M, Nickerson DA, Shendure J. Targeted capture and massively parallel sequencing of 12 human exomes. Nature. 2009; 461:272-276.

17. Liu X, Wang J, Chen L. Whole-exome sequencing reveals recurrent somatic mutation networks in cancer. Cancer Lett. 2013; 340:270-276.

18. Beltran H, Eng K, Mosquera JM, Sigaras A, Romanel A, Rennert H, Kossai M, Pauli C, Faltas B, Fontugne J, Park $\mathrm{K}$, Banfelder J, Prandi D, et al. Whole-exome sequencing of metastatic cancer and biomarkers of treatment response. JAMA Oncol. 2015; 1:466-474.

19. Hartgrink HH, Putter H, Klein Kranenbarg E, Bonenkamp JJ, van de Velde CJ, Dutch Gastric Cancer Group. Value of palliative resection in gastric cancer. Br J Surg. 2002; 89:1438-1443.

20. Xia X, Li C, Yan M, Liu B, Yao X, Zhu Z. Who will benefit from noncurative resection in patients with gastric cancer with single peritoneal metastasis? Am Surg. 2014; 80:124-130.

21. Lim B, Kim C, Kim JH, Kwon WS, Lee WS, Kim JM, Park JY, Kim HS, Park KH, Kim TS, Park JL, Chung HC, Rha $\mathrm{SY}$, et al. Genetic alterations and their clinical implications in gastric cancer peritoneal carcinomatosis revealed by whole-exome sequencing of malignant ascites. Oncotarget. 2016; 7:8055-8066. doi: 10.18632/oncotarget.6977.

22. Canbay E, Yonemura Y, Brucher B, Baik SH, Sugarbaker $\mathrm{PH}$. Intraperitoneal chemotherapy and its evolving role in management of gastric cancer with peritoneal metastases. Chin J Cancer Res. 2014; 26:1-3.

23. Guo L, Ou JL, Zhang T, Ma L, Qu LF. Effect of expressions of tumor necrosis factor alpha and interleukin $1 \mathrm{~B}$ on peritoneal metastasis of gastric cancer. Tumour Biol. 2015; 36:8853-8860.

24. Imano M, Itoh T, Satou T, Yasuda A, Nishiki K, Kato H, Shiraishi O, Peng YF, Shinkai M, Tsubaki M, Yasuda T, Imamoto $\mathrm{H}$, Nishida $\mathrm{S}$, et al. High expression of epithelial cellular adhesion molecule in peritoneal metastasis of gastric cancer. Target Oncol. 2013; 8:231-235.

25. Imano M, Okuno K. Treatment strategies for gastric cancer patients with peritoneal metastasis. Surg Today. 2014; 44:399-404.

26. Tan P, Yeoh KG. Genetics and molecular pathogenesis of gastric adenocarcinoma. Gastroenterology. 2015; 149:1153$1162 \mathrm{e} 1153$.

27. Kan Z, Jaiswal BS, Stinson J, Janakiraman V, Bhatt D, Stern HM, Yue P, Haverty PM, Bourgon R, Zheng J, Moorhead M, Chaudhuri S, Tomsho LP, et al. Diverse somatic mutation patterns and pathway alterations in human cancers. Nature. 2010; 466:869-873.
28. Das S, Sarkar A, Ryan KA, Fox S, Berger AH, Juncadella IJ, Bimczok D, Smythies LE, Harris PR, Ravichandran $\mathrm{KS}$, Crowe SE, Smith PD, Ernst PB. Brain angiogenesis inhibitor 1 is expressed by gastric phagocytes during infection with Helicobacter pylori and mediates the recognition and engulfment of human apoptotic gastric epithelial cells. FASEB J. 2014; 28:2214-2224.

29. Lee JH, Koh JT, Shin BA, Ahn KY, Roh JH, Kim YJ, Kim KK. Comparative study of angiostatic and anti-invasive gene expressions as prognostic factors in gastric cancer. Int J Oncol. 2001; 18:355-361.

30. Cajuso T, Hanninen UA, Kondelin J, Gylfe AE, Tanskanen $\mathrm{T}$, Katainen R, Pitkanen E, Ristolainen H, Kaasinen E, Taipale M, Taipale J, Bohm J, Renkonen-Sinisalo L, et al. Exome sequencing reveals frequent inactivating mutations in ARID1A, ARID1B, ARID2 and ARID4A in microsatellite unstable colorectal cancer. Int J Cancer. 2014; 135:611-623.

31. Li M, Zhao H, Zhang X, Wood LD, Anders RA, Choti MA, Pawlik TM, Daniel HD, Kannangai R, Offerhaus GJ, Velculescu VE, Wang L, Zhou S, et al. Inactivating mutations of the chromatin remodeling gene ARID2 in hepatocellular carcinoma. Nat Genet. 2011; 43:828-829.

32. Aso T, Uozaki H, Morita S, Kumagai A, Watanabe M. Loss of ARID1A, ARID1B, and ARID2 expression during progression of gastric cancer. Anticancer Res. 2015; 35:6819-6827.

33. Ko JM, Chan PL, Yau WL, Chan HK, Chan KC, Yu ZY, Kwong FM, Miller LD, Liu ET, Yang LC, Lo PH, Stanbridge EJ, Tang JC, et al. Monochromosome transfer and microarray analysis identify a critical tumorsuppressive region mapping to chromosome 13q14 and THSD1 in esophageal carcinoma. Mol Cancer Res. 2008; 6:592-603.

34. Khamas A, Ishikawa $\mathrm{T}$, Mogushi $\mathrm{K}$, Iida S, Ishiguro M, Tanaka H, Uetake H, Sugihara K. Genome-wide screening for methylation-silenced genes in colorectal cancer. Int J Oncol. 2012; 41:490-496.

35. Saunus JM, Quinn MC, Patch AM, Pearson JV, Bailey PJ, Nones K, McCart Reed AE, Miller D, Wilson PJ, Al-Ejeh F, Mariasegaram M, Lau Q, Withers T, et al. Integrated genomic and transcriptomic analysis of human brain metastases identifies alterations of potential clinical significance. J Pathol. 2015; 237:363-378.

36. Bae JA, Yoon S, Park SY, Lee JH, Hwang JE, Kim H, Seo YW, Cha YJ, Hong SP, Kim H, Chung IJ, Kim KK. An unconventional KITENIN/ErbB4-mediated downstream signal of EGF upregulates c-Jun and the invasiveness of colorectal cancer cells. Clin Cancer Res. 2014; 20:4115-4128.

37. Canfield K, Li J, Wilkins OM, Morrison MM, Ung M, Wells W, Williams CR, Liby KT, Vullhorst D, Buonanno A, Hu H, Schiff R, Cook RS, et al. Receptor tyrosine kinase ERBB4 mediates acquired resistance to ERBB2 inhibitors in breast cancer cells. Cell Cycle. 2015; 14:648-655. 
38. Gulino A, Di Marcotullio L, Screpanti I. The multiple functions of Numb. Exp Cell Res. 2010; 316:900-906.

39. Colaluca IN, Tosoni D, Nuciforo P, Senic-Matuglia F, Galimberti V, Viale G, Pece S, Di Fiore PP. NUMB controls p53 tumour suppressor activity. Nature. 2008; 451:76-80.

40. Ash S, Luria D, Cohen IJ, Goshen Y, Toledano H, Issakov J, Yaniv I, Avigad S. Excellent Prognosis in a Subset of
Patients with Ewing Sarcoma Identified at Diagnosis by CD56 Using Flow Cytometry. Clin Cancer Res. 2011; 17:2900-2907.

41. Desjardins S, Beauparlant JC, Labrie Y, Ouellette G, Durocher F, Inherit BRCAs. Variations in the NBN/NBS1 gene and the risk of breast cancer in non-BRCA1/2 French Canadian families with high risk of breast cancer. BMC Cancer. 2009; 9:181. 